Buana Sains Vol 18 No 1: 35 - 46, 2018

\title{
KETERSEDIAAN NITROGEN DAN POPULASI BAKERI TANAH DALAM SISTEM TANAM SRI (System of Rice Intensification)
}

\author{
Nurul Istiqomah ${ }^{1}$, T. Naomi Indarto ${ }^{2}$, V. Amien Nugroho ${ }^{2}$ dan Cahyo Prayogo ${ }^{2}$ \\ ${ }^{1}$ Balai Pengkajian Teknologi Pertanian Jawa Timur \\ ${ }^{2}$ Jurusan Tanah Fakultas Pertanian Universitas Brawijaya
}

\begin{abstract}
The obstacles that caused the declining of rice production is due to the reduction of soil fertility status. Various efforts were made to increase the production such as intensification and expansion in rice farming system. SRI cropping systems an alternative technique for improving soil productivity following maintaining water uses under an aerobic condition which exaggerated the raising of microorganisms activities in soil and improving the availability of nutrients particularly nitrogen status.

This study was aimed to examine the impact of SRI system on mineral N status along with the population of soil bacteria which involving in nitrogen dynamic. The research was conducted in October 2015-March 2016 in Kepanjen-Malang using Randomized Block Design with 4 treatments and 4 replicates. Soil sampling was conducted at 0 and 100 Day After Planting (DAP) collecting at a depth of $0-20 \mathrm{~cm}$ and $20-40 \mathrm{~cm}$. Measured soil parameter was including $\mathrm{pH}$, organic- $\mathrm{C}$, mineral $\mathrm{N}(\mathrm{NH} 4+$ and NO3-). Soil bacteria are identified using plate count method (spread plate) for estimating their population. Analysis of Variance (ANOVA) was used followed by Duncan test at 5\% level along with correlation and regression analysis.

The results showed that the SRI cultivation system can increase the mineral $\mathrm{N}$ at the level of $14.09 \mathrm{ppm}$ compared to their initial value, amounting to $57.48 \mathrm{ppm}$ of Nitrate and the bacterial population at the level of $6.25 \times 108$ cfu $\mathrm{g}-1$. The best treatment was found under the combination of NPK (15-15-15) and biofertilizer yielded at $8.42 \mathrm{t}$ ha-1. Multivariate analysis results indicate that P0 treatment significantly different with treatment P1, P2, and P3. However, the treatment of P1 were not significantly different P3.
\end{abstract}

Keywords: SRI system; nitrogen; bacteria; NPK; biofertilizer

\section{Pendahuluan}

Padi merupakan tanaman pokok yang paling penting yang menyediakan 532 juta ton beras, setiap orang mengkonsumsi rata-rata sekitar $80 \mathrm{~kg}$ beras, $66 \mathrm{~kg}$ gandum dan hanya $17 \mathrm{~kg}$ jagung kapita ${ }^{-1}$ tahun $^{-1}$ (FAOSTAT, 2013). Di Indonesia, berdasarkan data dari Badan Pusat Statistik (2008), nilai permintaan beras di Indonesia mencapai
$139 \mathrm{~kg} \mathrm{kapita}{ }^{-1}$ tahun $^{-1}$. Produksi padi tahun 2014 diperkirakan sebanyak 70,61 juta ton, dan mengalami penurunan sebanyak 0,67 juta ton atau sekitar 0,94\% dibandingkan tahun 2013 yang produksinya mencapai 71,28 juta ton. Jumlah produksi beras yang tidak stabil ini dinilai masih kurang untuk memenuhi permintaan yang selalu meningkat setiap tahunnya. Untuk memenuhi permintaan pangan dunia pada tahun 2025, produksi 
N.Istiqomah, T. N. Indarto, V. A. Nugroho dan C. Prayogo/ Buana Sains Vol 18 No 1 : 35-46

beras harus ditingkatkan sebesar $60 \%$ (Fageria, 2007).

Berbagai macam upaya dilakukan untuk meningkatkan produksi seperti intensifikasi dan ekstensifikasi pertanian. Akan tetapi salah satu kendala yang menyebabkan lambatnya tingkat pertumbuhan hasil produksi sawah adalah degradasi lahan, penurunan kesuburan tanah, dan ketersediaan air (Dobermaan, 2004). Sistem pertanian pada umumnya (konvensional) juga memiliki dampak negatif pada lingkungan karena penggunaan air dalam jumlah besar serta kandungan residu bahan kimia pertanian dan herbisida yang menyebabkan pencemaran air dan tanah (Khidhir et al., 2011). Oleh karena itu perlu adanya inovasi budidaya padi yang berproduksi tinggi tanpa merusak alam dan meminimalisir penggunaan air.

Ada berbagai macam sistem budidaya padi yang diterapkan di dunia pertanian seperti BMP (Best Management Practices), FP (Farmer Practices) dan SRI (System of Rice Intensification). Akan tetapi yang dinilai baik untuk lingkungan yaitu sistem SRI pada tanaman padi. Barkelaar (2001) mengungkapkan bahwa sistem SRI ini mampu memberikan hasil panen 2 kali lipat dibandingkan dengan sistem konvensional. Selain itu, Sinha (2007) mengungkapkan bahwa menurut beberapa penelitian, sistem SRI yang diterapkan di Sri Lanka memberikan hasil yang lebih tinggi dibanding sistem konvensional. Pada penelitian di China juga menunjukkan bahwa sistem SRI menghasilkan padi 35,6\% lebih tinggi dibanding sistem konvensional. Sistem SRI ini terdiri dari 6 komponen yaitu baris tanam tunggal, penanaman bibit muda dengan jarak yang lebar, penyiangan secara mekanis, penggunaan bahan organik, dan AWD atau Alternate Wetting and Drying (Krupnik et al., 2012). Pada sistem SRI, penggunaan air irigasi sangat diperhitungkan untuk menjaga kondisi lahan agar lembab tetapi tidak tergenang, sehingga penggunaan air akan lebih efisien. Dengan kondisi tanah yang aerob, aktifitas mikroorganisme di dalam tanah juga akan meningkat dan akan berpengaruh terhadap ketersediaan unsur hara di dalam tanah (Chang et al., 2015).

Di lahan percobaan yang berlokasi di Pakisaji Kabupaten Malang, para petani sering kali mengalami permasalahan minimnya sumber air dan banyaknya petani yang membudidayakan padi secara konvensional menjadi salah satu masalah yang perlu diperhatikan di lahan tersebut. Oleh karena itu, dalam penelitian ini ingin diketahui sejuah mana perbedaan dari perubahan dari sistem konvensional ke sistem SRI. terhadap dinamika mineral $\mathrm{N}$, dan populasi bakteri tanah, dan pengaruhnya terhadap produktivitas padi

\section{Metode Penelitian}

Penelitian ini dilaksanakan di Desa Karangduren, Kecamatan Pakisaji, Kabupaten Malang, Jawa Timur. Analisis tanah dan tanaman dilakukan di Laboratorium Kimia Tanah Jurusan Tanah Fakultas Pertanian Universitas Brawijaya, Malang. Penelitian ini dilaksanakan pada bulan AgustusDesember 2015. Metode penelitian yang digunakan dalam percobaan ini yaitu metode Rancangan Acak Kelompok (RAK) di lapangan. Petak percobaan berukuran $8 \mathrm{~m}$ x 4,5 m (36 $\left.\mathrm{m}^{2}\right)$ dan jarak antar petak percobaan $60 \mathrm{~cm}$. Perlakuan yang diuji dalam penelitian ini ada 4 buah dengan 4 ulangan yang menghasilkan 16 kombinasi perlakuan. Dosis pemupukan tiap petak percobaan beserta perlakuan yang digunakan terdapat pada Tabel 1. 
N.Istiqomah, T. N. Indarto, V. A. Nugroho dan C. Prayogo/ Buana Sains Vol 18 No 1 : 35-46

Tabel 1. Dosis pemberian pupuk pada sistem SRI

\begin{tabular}{llccc}
\hline Perlakuan & Kode & $\begin{array}{c}\text { Dosis Urea } \\
(\mathrm{kg} / \text { petak })\end{array}$ & $\begin{array}{c}\text { Dosis NPK 15- } \\
15-15 \\
(\mathrm{~kg} / \text { petak) }\end{array}$ & $\begin{array}{c}\text { Dosis Pupuk } \\
\text { Hayati } \\
\text { (liter/petak) }\end{array}$ \\
Kontrol & P0 & 0,36 & & \\
SRI (NPK 15-15-15) & P1 & 0,36 & 1,08 & 11,25 \\
SRI (Pupuk Hayati) & P2 & 0,36 & & 11,25 \\
SRI (NPK 15-15-15 + Pupuk & P3 & 0,36 & 1,08 & \\
Hayati) & & & & \\
\hline
\end{tabular}

Tahapan pelaksanaan penelitian sismtem SRI ini mualai dari proses penanaman sampai dengan panen. Tanaman padi varietas ciherang umur 15 hari setelah semai dilakukan pindah tanam ke lahan. Penanaman 1 bibit per lubang tanam dengan membentuk akar (L) (Latief et al., 2006). Pemberian air pada saat fase vegetatif diberikan secara berselang dengan penggenengan dan pengeringan (Latief et al., 2006). Penyulaman dilakukan pada tanaman yang mati sampai pada 7 HST. Pengendalian gulma dilakukan dengan cara manual dan mekanis menggunakan rotary landak pada umur tanam 10, 20, 30 dan 40 hari setelah tanam (Uphoff, 2003). Perlakuan pemupukan dilakukan pada 15, 30 dan 45 hari setelah tanam dengan menggunakan pupuk urea, NPK 15-15-15 serta pupuk hayati. Pemanenan menggunakan metode ubinan ukuran 2,5 x 2,5 $\mathrm{m}^{2}$ yang diambil setiap petak (Damiri dan Ishak, 2011). Pengamatan tinggi tanam dan jumlah anakan menggunakan plot ukuran $1 \mathrm{~m}^{2}$ yang dilakukan 30, 60, 90 HST (Tsujimoto et al., 2009). Pengamatan bobot 1000 butir diperoleh dengan menimbang 1000 butir gabah bernas yang dihasilkan tanaman setelah panen pada kadar air gabah 14\% dan hasil gabah per hektar dihitung dengan mengkonversi bobot gabah dari seluruh rumpun dalam satu luasan pertanaman menjadi bobot gabah dalam ton per hektar (Puspitawati, 2013).
Pengambilan sampel tanah dilakukan pada 0 HST (sebelum tanam) dan 100 HST. Sampel tanah diambil pada kedalaman $0-20 \mathrm{~cm}$ dan $20-40 \mathrm{~cm}$ yang kemudian disimpan di dalam kulkas. Sifat kimia tanah yang dianalisis adalah $\mathrm{pH}$ $\mathrm{H}_{2} \mathrm{O}$, C-organik, mineral $\mathrm{N}\left(\mathrm{NH}_{4}^{+}\right.$dan $\mathrm{NO}_{3}{ }^{-}$). Sedangkan aspek biologi dihitung populasi bakteri dengan menggunakan metode plate count (spread plate). Analisis data menggunakan Analysis of Variance ( $A N O V A$ ) yang dilanjutkan dengan $\mathrm{Uji}$ Duncan pada taraf $5 \%$, uji korelasi dan regresi untuk mengetahui keeratan hubungan antar parameter, dan Multivariate Analysis dengan pendekatan Canonical Variate Analysis (CVA) untuk mengelompokkan hubungan antar perlakuan berdasarkan parameter yang berpengaruh.

\section{Hasil dan Pembahasan}

Sebelum kegiatan penanaman dan pemberian perlakuan, dilakukan analisis kimia dan biologi awal. Analisis awal ditujukan untuk mengetahui nilai awal dari setiap parameter, sehingga dapat diketahui perbedaan sebelum dan sesudah perlakuan. Berikut merupakan hasil analisis kimia dan biologi tanah awal pada berbagai parameter pengamatan (Tabel 2). 
N.Istiqomah, T. N. Indarto, V. A. Nugroho dan C. Prayogo/ Buana Sains Vol 18 No 1 : 35-46

Tabel 2. Sifat Kimia dan Biologi Tanah Awal sebelum perlakuan

\begin{tabular}{lcc}
\hline Parameter & \multicolumn{2}{c}{ Kedalaman (cm) } \\
\hline & $\mathbf{0 - 2 0}$ & $\mathbf{2 0 - 4 0}$ \\
\hline $\mathrm{pH}$ & 5.8 & 5.8 \\
\hline $\mathrm{C}-$ Organik (\%) & 2.00 & 1.91 \\
\hline $\mathrm{NH}_{4}^{+}(\mathrm{ppm})$ & 3.78 & 6.89 \\
\hline $\mathrm{NO}_{3}^{-}(\mathrm{ppm})$ & 5.08 & 10.59 \\
\hline $\mathrm{N}$-total (\%) & 0.18 & 0.11 \\
\hline Populasi Bakteri (cfu g-1) & $4.3 \times 108$ & $2.7 \times 108$ \\
\hline
\end{tabular}

$\mathrm{pH}$ pada kedua kedalaman memiliki nilai yang sama yaitu 5.8. Kandungan C-Organik pada kedua kedalaman berbeda yaitu $2.00 \%$ pada kedalaman $0-20 \mathrm{~cm}$ dan $1.91 \%$ pada kedalaman $20-40 \mathrm{~cm}$. Hal yang berbeda ditemui pada kandungan ammonium dan nitrat yang memiliki nilai yang lebih tinggi pada kedalaman $20-40 \mathrm{~cm}$. Untuk ammonium pada kedalaman $0-20 \mathrm{~cm}$ nilainya sebesar $3.78 \mathrm{ppm}$ dan untuk kedalaman $20-40 \mathrm{~cm}$ sebesar 6.89 ppm. Pada parameter nitrat, untuk kedalaman 0-20 cm kandungannya sebesar 5.08 ppm, sedangkan pada kedalaman 20-40 cm sebesar 10.59 ppm. Berdasarkan hasil analisis awal, dapat dilihat bahwa nilai populasi bakteri pada kedalaman $0-20 \mathrm{~cm}$ sebesar $4.3 \times 10^{8} \mathrm{cfu} \mathrm{g}^{-1}$. Nilai ini lebih tinggi apabila dibandingkan dengan kedalaman 20-40 cm yang memiliki populasi bakteri sebanyak $2.7 \times 10^{8} \mathrm{cfu}$ g.

\section{Pengaruh perlakuan terhadap sifat kimia dan biologi tanah}

Terdapat perbedaan yang signifikan $(\mathrm{P}<0.05)$ akibat perbedaan perlakuan pada sistem SRI, terutama pada perlakuan P2 (SRI + Pupuk Hayati) jika dibandingkan dengan perlakuan lain terhadap status C-Organik tanah. Nilai C-Organik yang paling tinggi terdapat pada perlakuan P0 untuk kedalaman 0-20 $\mathrm{cm}$ yaitu sebesar 1,69\%. Untuk nilai COrganik terendah terdapat pada perlakuan P2. Pada kedalaman $20-40 \mathrm{~cm}$, nilai C-Organik yang paling tinggi terdapat pada perlakuan P1 yaitu sebesar $1,32 \%$, sedangkan untuk nilai terendah sama seperti pada kedalaman $0-20 \mathrm{~cm}$, yaitu perlakuan P2 dengan nilai $1,22 \%$. Hal yang berbeda ditemui pada kedalaman 20-40 cm, dimana perlakuan tidak berbeda nyata dengan kontrol. Akan tetapi sama seperti pada kedalaman 0-20 cm, perlakuan P2 dan P3 memiliki C-organik lebih rendah dari perlakuan P1 dan kontrol (Gambar 1).

Penurunan C-Organik ini diduga akibat peningkatan aktivitas mikrorganisme tanah. Hal ini dikarenakan C-Organik merupakan sumber makanan bagi bakteri di dalam tanah. Santosa (2012), menyatakan bahwa penambahan C-Organik dapat meningkatan aktifitas bakteri dan mikroba tanah. Hal ini sesuai dengan pernyataan Ayaga et al. (2006) yang mengungkapkan bahwa penambahan bahan organik dalam tanah dapat mendukung pertumbuhan dan aktifitas mikroba di dalam tanah.

Nilai pH pada masing-masing perlakuan tidak berbeda nyata. Akan tetapi terjadi peningkatan nilai $\mathrm{pH}$ pada setiap perlakuan. Nilai $\mathrm{pH}$ yang paling tinggi terdapat pada perlakuan P3 dengan nilai 6,40 yang diikuti dengan perlakuan P2 dengan nilai 6,39, perlakuan P1 dengan nilai 6,38 dan yang paling rendah terdapat pada perlakuan P0 dengan nilai 6,34 . 
N.Istiqomah, T. N. Indarto, V. A. Nugroho dan C. Prayogo/ Buana Sains Vol 18 No 1 : 35-46

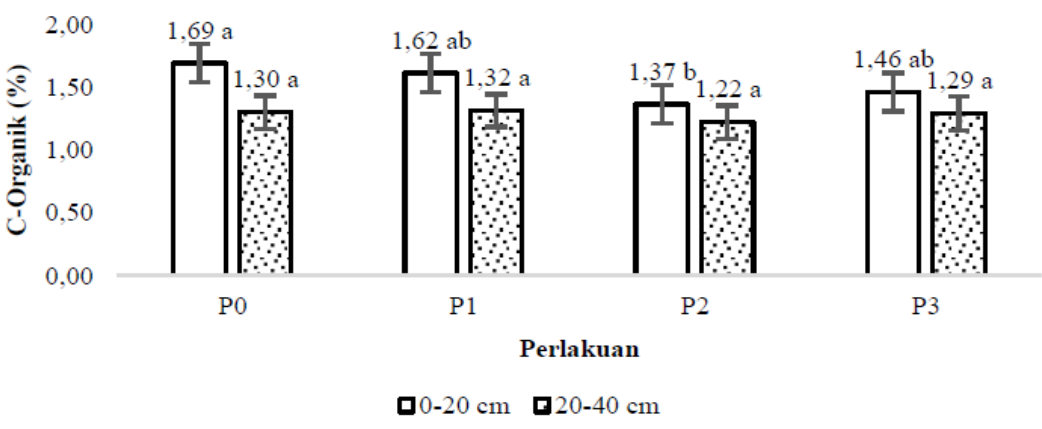

Gambar 1. Kandungan C-Organik tanah pada umur 100 HST

Keterangan : P0 (kontrol), P1 (NPK 15-15-15), P2 (Pupuk Hayati), P3 (NPK 15-15-15 + Pupuk Hayati); Huruf yang berbeda menunjukan perbedaan yang nyata pada uji Duncan taraf $5 \%$; Garis vertikal menunjukkan nilai LSD uji Duncan 5\%. Panjang garis vertikal yang tidak bersinggungan antar perlakuan pada kedalaman yang sama menunjukkan pengaruh yang signifikan antar perlakuan.

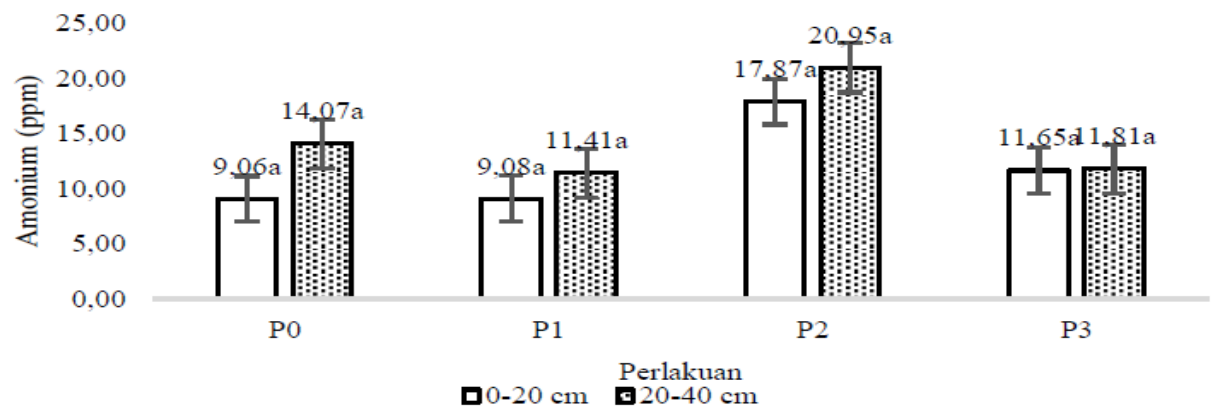

Gambar 2. Kandungan Amonium $\left(\mathrm{NH}_{4}^{+}\right)$tanah pada umur $100 \mathrm{HST}$

Keterangan : P0 (kontrol), P1 (NPK 15-15-15), P2 (Pupuk Hayati), P3 (NPK 15-15-15 + Pupuk Hayati); Huruf yang berbeda menunjukan perbedaan yang nyata pada uji Duncan taraf $5 \%$; Garis vertikal menunjukkan nilai LSD uji Duncan 5\%. Panjang garis vertikal yang tidak bersinggungan antar perlakuan pada kedalaman yang sama menunjukkan pengaruh yang signifikan antar perlakuan.

Berdasarkan analisis sidik ragam (ANOVA) tidak didapatkan hasil yang significant $(\mathrm{P}<0.05)$ terhadap kandungan amonium pada kedalaman $0-20 \mathrm{~cm}$ antar perlakuan. Hal yang sama juga ditemukan pada kedalaman $20-40 \mathrm{~cm}$. Akan tetapi ada kecenderungan kandungan Amonium $\left(\mathrm{NH}_{4}^{+}\right)$pada perlakuan P2 lebih tinggi dibandingkan dengan kontrol dan perlakuan yang lain (Gambar 2). Hal yang berbeda didapatkan pada kandungan Nitrat $\left(\mathrm{NO}_{3}{ }^{-}\right)$. Kandungan nitrat tertinggi terdapat pada perlakuan P2 (SRI+ Pupuk Hayati) dengan nilai 62,56 ppm, sedangkan untuk nilai terendah terdapat pada perlakuan P0 dengan kandungan nitrat 36,23 ppm pada kedalaman tanah 0-20 cm. Sedangkan pada kedalaman 20-40 cm perlakuan tidak memberikan pengaruh yang nyata terhadap kandungan Nitrat $\left(\mathrm{NO}_{3}{ }^{-}\right)$. 


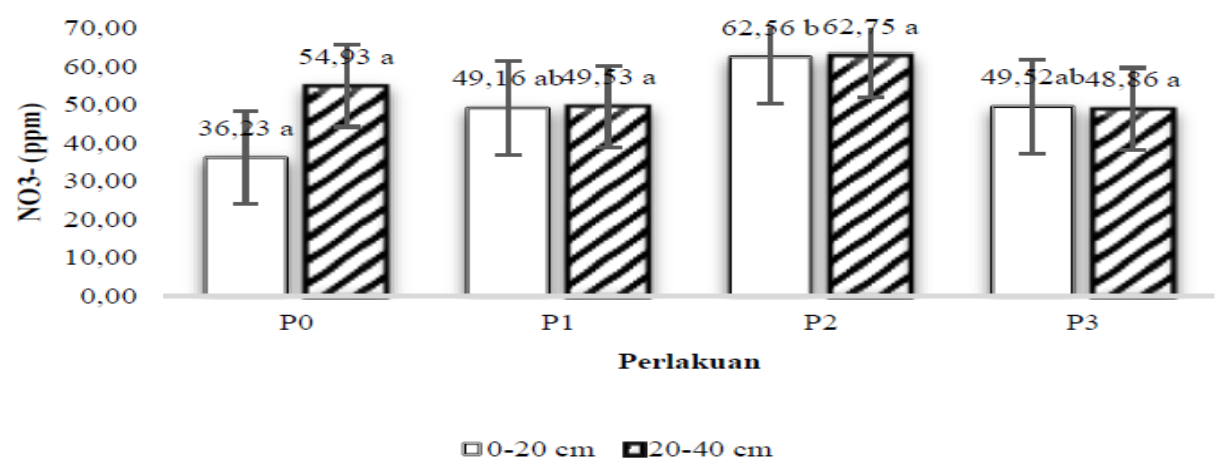

Gambar 3. Kandungan Nitrat $\left(\mathrm{NO}_{3}^{-}\right)$pada umur 100 HST

Keterangan : P0 (kontrol), P1 (NPK 15-15-15), P2 (Pupuk Hayati), P3 (NPK 15-15-15 + Pupuk Hayati); Huruf yang berbeda menunjukan perbedaan yang nyata pada uji Duncan taraf $5 \%$; Garis vertikal menunjukkan nilai LSD uji Duncan 5\%. Panjang garis vertikal yang tidak bersinggungan antar perlakuan pada kedalaman yang sama menunjukkan pengaruh yang signifikan antar perlakuan

Nitrat $\left(\mathrm{NO}_{3}^{-}\right)$atau merupakan bentuk nitrogen di dalam tanah yang mudah diserap oleh tanaman. Apabila dibandingkan dengan analisis awal baik amonium maupun nitrat mengalami peningkatan 12 kali lipat pada kedalaman $0-20 \mathrm{~cm}$ dan 9 kali lipat pada kedalaman 20-40 cm, dimana peningkatan yang paling tinggi terdapat pada perlakuan P2 (SRI + Pupuk Hayati). Hal ini dikarenakan adanya penambahan pupuk hayati, dimana pupuk hayati menyediakan bakteri yang berperan penting dalam proses nitrifikasi. Kandungan nitrat yang ada pada lahan SRI ini sama seperti ammonium yang dipengaruhi oleh aplikasi pupuk dan manajemen pemberian air irigasi. Kyuma, (1995) mengungkapkan bahwa setelah satu bulan atau lebih dari awal penggenangan, akan terbentuk lapisan oksidasi dan lapisan reduksi. Ketika ammonium berada pada lapisan oksidasi, bakteri yang berperan dalam proses nitrifikasi akan langsung mengubah ammonium tersebut menjadi nitrat.

Berdasarkan hasil analisis dan perhitungan populasi bakteri, dapat dilihat bahwa semua perlakuan berbeda nyata $(\mathrm{P}<0.05)$ dibandingkan dengan kontrol. Jumlah populasi bakteri pada masing-masing perlakuan lebih tinggi apabila di bandingkan dengan kontrol. Gambar 4 menunjukkan bahwa populasi tertinggi berada pada kedalaman 0-20 yaitu pada perlakuan P3 dengan jumlah $10,55 \times 10^{9} \mathrm{cfu}^{-1}$, sedangkan populasi terendah terdapat pada perlakuan P0 dengan jumlah populasi sebesar 9,32 $\mathrm{x}$ $109 \mathrm{cfu} \mathrm{g}^{-1}$. Pada perlakuan P1 memiliki jumlah populasi bakteri sebesar 9,92 x $10^{9}$ cfu g-1. Untuk perlakuan P3 populasinya sebesar $9,97 \times 10^{9} \mathrm{cfu} \mathrm{g}^{-1}$.

Pada kedalaman 20-40 cm, populasi bakteri yang paling tinggi terletak pada perlakuan P3 dengan jumlah populasi bakteri $10,18 \times 10^{9} \mathrm{cfu} g$ ${ }^{1}$. Untuk populasi terendah sama seperti pada kedalaman $0-20 \mathrm{~cm}$, terletak pada perlakuan P0 dengan jumlah populasi $8,99 \times 10^{9} \mathrm{cfu} \mathrm{g}^{-1}$. Jumlah populasi bakteri pada kedalaman 20-40 cm ini meningkat apabila dibandingkan dengan kontrol. Apabila dibandingkan dengan analisis awal, populasi bakteri mengalami peningkatan sebesar 24,5\%. (Gambar 4). 


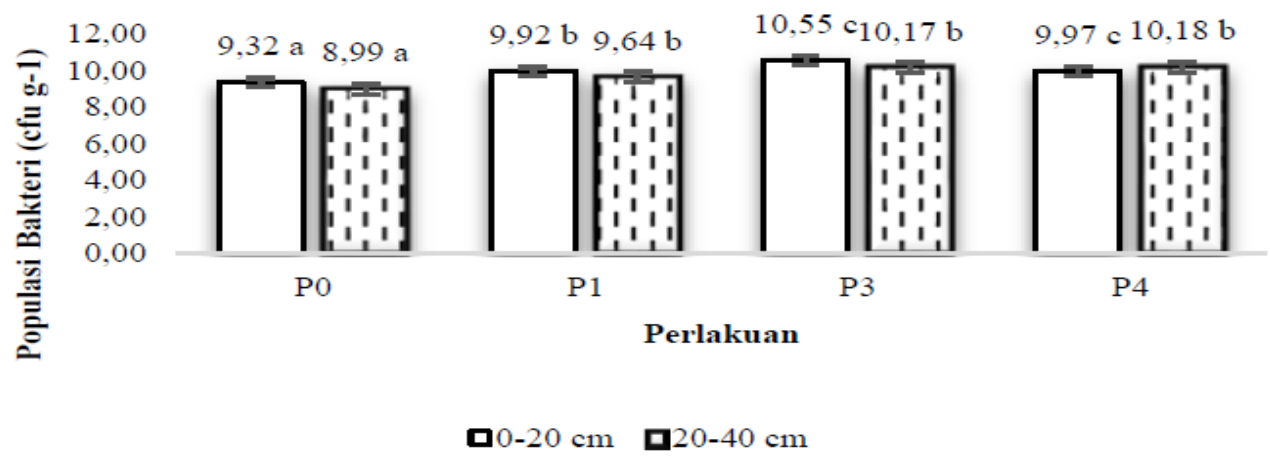

Gambar 4. Populasi bakteri pada umur 100 HST

Keterangan : P0 (kontrol), P1 (NPK 15-15-15), P2 (Pupuk Hayati), P3 (NPK 15-15-15 + Pupuk Hayati); Huruf yang berbeda menunjukan perbedaan yang nyata pada uji Duncan taraf 5\%; Garis vertikal menunjukkan nilai LSD uji Duncan 5\%. Panjang garis vertikal yang tidak bersinggungan antar perlakuan pada kedalaman yang sama menunjukkan pengaruh yang signifikan antar perlakuan.

Menurut Chang et al. (2015) dikarenakan metode SRI memiliki sistem irigasi yang menyebabkan tanah menjadi aerob, aktifitas mikroorganisme di dalam tanah juga akan meningkat dan akan berpengaruh terhadap ketersediaan unsur hara di dalam tanah. Selain itu, manajemen irigasi pada SRI (tanah aerob) juga akan berdampak pada proses nitrifikasi dimana Amonium $\left(\mathrm{NH}_{4}^{+}\right)$pada lapisan oksidasi akan mengalami nitrifikasi dan berubah menjadi Nitrat $\left(\mathrm{NO}_{3}{ }^{-}\right)$. Perubahan ammonium menjadi Nitrat ini tidak terlepas dari peran bakteri nitrifikasi yang semakin aktif (Chang et al. 2015; Kyuma, 1995). Untuk populasi bakteri, apabila dibandingkan dengan hasil analisis awal (Tabel 1), terjadi peningkatan sebesar 24,5 kali lipat pada kedalaman 0-20 cm dan 38 kali lipat pada kedalaman 20-40 cm, terutama pada perlakuan aplikasi pupuk hayati (kode P2 dan P3). Hal ini sejalan dengan Gayatry, (2002) yang mengungkapkan bahwa penerapan sistem SRI sendiri dapat meningkatkan populasi bakteri lebih tinggi dibandingkan dengan sistem konvensional. Peningkatan yang ada pada perlakuan aplikasi NPK (15-15-15) dan kontrol diduga karena pengaruh dari penerapan sistem SRI. Hal ini sejalan dengan pernyataan Chang et al. (2015) yang mengungkapkan bahwa SRI dapat meningkatkan aktifitas mikroorganisme di dalam tanah dan penambahan bahan organik yang befungsi untuk menambah asupan makanan untuk bakteri yang ada di dalam tanah (Rajendran dan Ganesa, 2015).

\section{Pengaruh perlakuan terhadap produksi padi}

Gambar 5 menjelaskan bahwa terdapat pengaruh yang signifikan $(\mathrm{P}<0.05)$ terhadap produsi padi. perlakuan P3 (NPK 5-15-15 + Pupuk Hayati) memiliki berat 1000 biji tertinggi $(30,31 \mathrm{~g})$, sedangkan pada perlakuan P0 (Kontrol) yang terendah (28.32 g) yang kemudian diikuti dengan perlakuan P1 (NPK 1515-15) sebesar 29,5 g. 


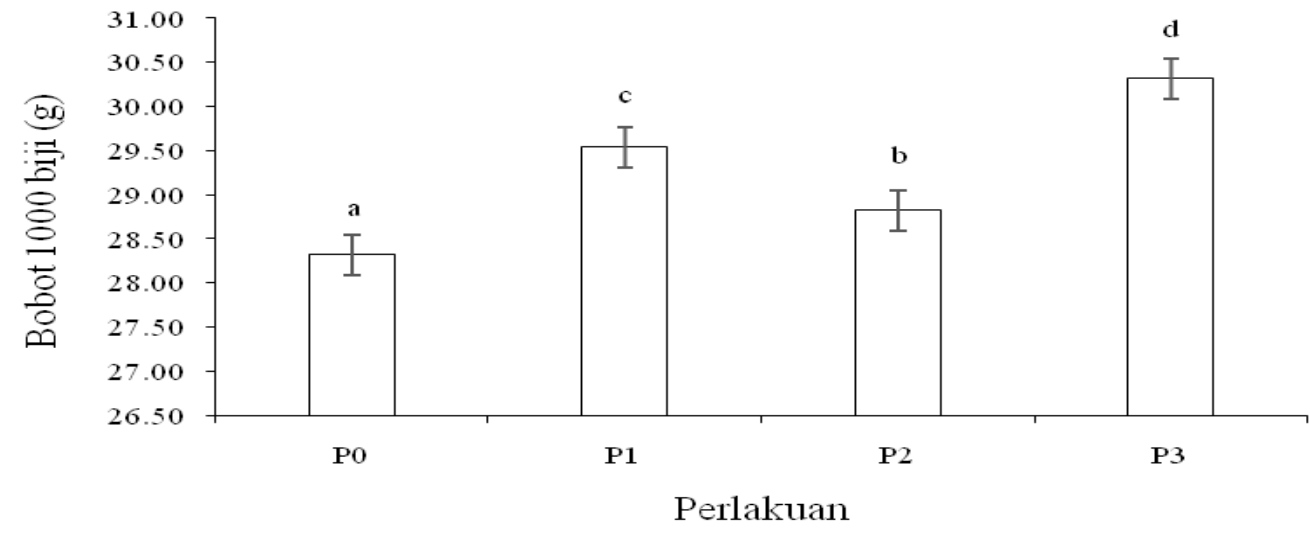

Gambar 5. Rerata Bobot 1000 Biji

Keterangan : P0 (kontrol), P1 (NPK 15-15-15), P2 (Pupuk Hayati), P3 (NPK 15-15-15 + Pupuk Hayati);Huruf yang berbeda menunjukan perbedaan yang nyata pada uji Duncan taraf 5\%; Garis vertikal menunjukkan nilai LSD uji Duncan 5\%. Panjang garis vertikal yang tidak bersinggungan antar perlakuan menunjukkan perbedaan nyata antar perlakuan.

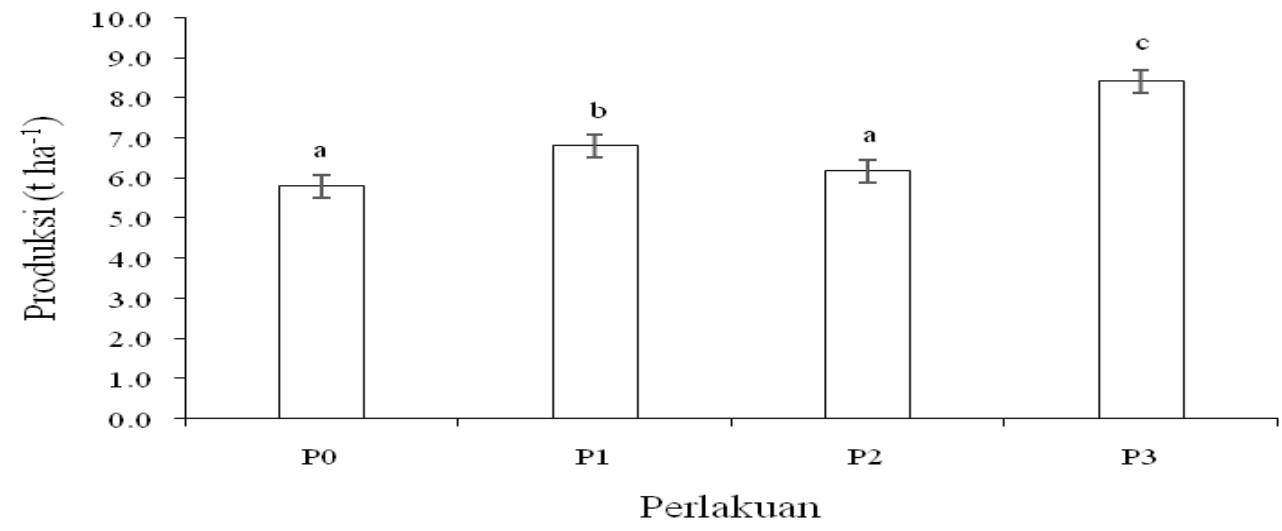

Gambar 6. Rerata produksi padi

Keterangan : P0 (kontrol), P1 (NPK 15-15-15), P2 (Pupuk Hayati), P3 (NPK 15-15-15 + Pupuk Hayati); Huruf yang berbeda menunjukan perbedaan yang nyata pada uji Duncan taraf 5\%; Garis vertikal menunjukkan nilai LSD uji Duncan 5\%. Panjang garis vertikal yang tidak bersinggungan antar perlakuan menunjukkan pengaruh yang signifikan antar perlakuan.

Gambar 6 menjelaskan pengaruh perlakuan terhadap produksi padi (t ha ${ }^{1}$ )pada perlakuan P3 (NPK 15-15-15 + Pupuk Hayati) berbeda sangat nyata terhadap perlakuan $\mathrm{P} 1, \mathrm{P} 2$, dan $\mathrm{P} 0$. Perlakuan P3 (NPK 15-15-15 + Pupuk Hayati) memperoleh hasil produksi tertinggi yaitu $8,4 \mathrm{t} \mathrm{ha}^{-1}$ dan perlakuan P0 (kontrol) memiliki hasil produksi terendah yaitu 5,8 $\mathrm{t} \mathrm{ha}^{-1}$. Perlakuan P1
(NPK 15-15-15) berbeda nyata terhadap perlakuan P2 (Pupuk Hayati) dan perlakuan P0 (Kontrol). Peningkatan hasil produksi diperoleh pada perlakuan P1 (NPK 15-15-15) dengan hasil 6,8 tha ${ }^{1}$ lebih tinggi jika dibandingkan dengan perlakuan P2 (Pupuk Hayati) dan P0 (Kontrol). Perlakuan P3 (NPK 15-15-15 + Pupuk Hayati) memiliki dampak terhadap produksi tanaman padi metode 
N.Istiqomah, T. N. Indarto, V. A. Nugroho dan C. Prayogo/ Buana Sains Vol 18 No 1 : 35-46

SRI jika dibandingkan dengan perlakuan P0 (Kontrol) dengan peningkatan 2,6 t ha ${ }^{-1}$.

Berkaitan dengan hasil produksi, setelah dilakukan pengujian pada hasil panen ubinan didapatkan hasil bahwa panen tertinggi berada pada perlakuan P3 atau kombinasi dari pupuk NPK (15-1515) dan pupuk hayati. Produksi yang tinggi pada P3 dan P1 dikarenakan adanya aplikasi pupuk NPK (15-15-15), dimana unsur hara yang dibutuhkan oleh tanaman langsung tersedia dan dapat diserap. Berbeda halnya dengan P0 dan P2 yang tidak mendapatkan asupan pospor dan kalium, produksi pada kedua perlakuan tersebut cenderung lebih rendah. Berdasarkan beberapa penelitian, secara umum sistem SRI sendiri mampu meningkatkan hasil produksi walaupun hasil dari penerapan sistem SRI dapat berbeda tergantung pada faktor lain yang mempengaruhinya, seperti serangan nematoda, hama, manajemen budidaya, iklim, dan berbagai macam faktor alam lainnya (Uphoff et al., 2009).

\section{Hubungan Populasi Bakteri Terhadap Nitrat}

Berdasarkan hasil korelasi, didapatkan hasil bahwa hubungan korelasi antara parameter populasi bakteri dan nitrat memiliki hubungan yang paling kuat dibandingkan dengan parameter lainnya. Hal ini ditunjukkan dengan nilai $r$ sebesar 0,51. Keeratan hubungan dan model data dari kedua parameter tersebut dan hasil koefisien determinasinya adalah mengikuti pola garis linear dapat dilihat pada gambar 7 berikut.

Pada gambar 7, untuk hasil koefisien determinasi $\left(\mathrm{R}^{2}\right)$ dari populasi bakteri dengan nitrat dapat diketahui bahwa persentasi data hubungan antara populasi bakteri dan kandungan nitrat mencapai 26\% dengan mengikuti pola sebaran garis linear dengan formula : $\mathrm{y}=$ 8,7168x - 34,1. Dimana, y adalah kadungan nitrat $\left(\mathrm{NO}_{3}{ }^{-}\right)$dan $\mathrm{x}$ adalah poulasi bakteri. Sehingga dapat disimpulkan bahwa apabila populasi bakteri meningkat 1 cfu g-1, maka nitrat akan meningkat sebesar 8,71 ppm. Hal ini didukung oleh Kyuma, (1995) yang mengungkapkan bahwa bakteri memiliki pengaruh yang besar terhadap kandungan nitrat di dalam tanah karena bakteri berperan penting dalam proses nitrifikasi. Masih rendahnya huunbungan ini disebabkan tidak semua populasi bakteri yang diamati merupakan bakteri yang berpotensi melakukan proses nitrifikasi yang merubah $\mathrm{NH}_{4}+$ menjadi $\mathrm{NO}_{3}$

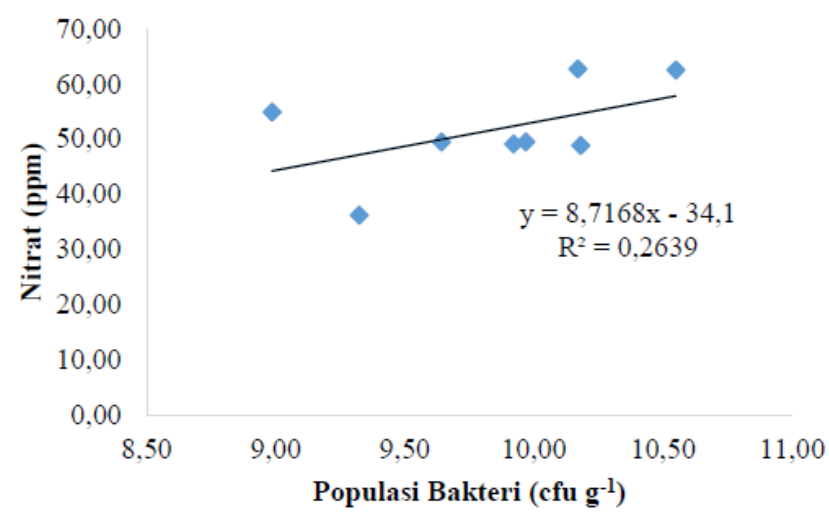

Gambar 7. Rerata produksi padi 


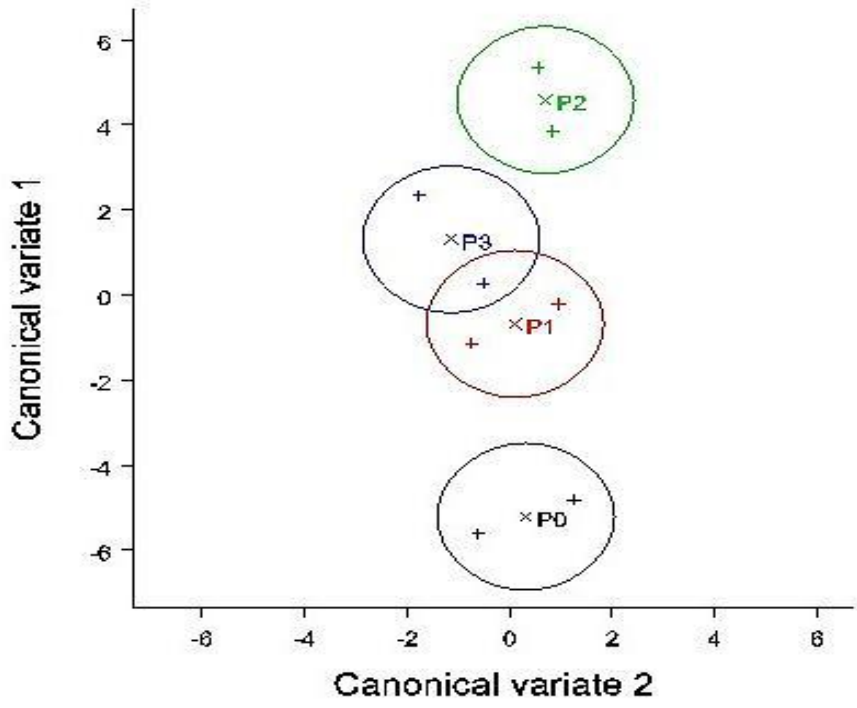

Gambar 8. Multivariate dengan pendekatan Canonical Variate

Berdasarkan hasil analisis multivariate yang terdiri dari paremeter : C-organik, $\mathrm{PH}$, mineral $\mathrm{N}$ dan populasi bakteri dengan pendekatan Canonical Variate menunjukkan bahwa pada perlakuan P0 berbeda nyata dengan perlakuan P1, P2 dan P3, dengan persentasi karagaman 95,41\% untuk CV1 dan 3,60\% untuk CV2 (gambar 8). Hal ini ditandai dengan lingkaran selang kepercayaan yang tidak bersinggungan. Namun, berbeda halnya dengan perlakuan P1 yang tidak berbeda nyata dengan P3, ditandai dengan lingkaran selang kepercayaan yang tidak terpisah dan bersinggungan (overlapping). Secara umum dapat disimpulkan bahwa analisis multivariate yang didapat menggolongkan atau mengroupkan perlakuan berdasarkan berbagi jenis parameter yang diamati.

\section{Kesimpulan}

1. 1.Penerapan sistem SRI yang ditambahkan pupuk hayati mampu meningkatkan Amonium $\left(\mathrm{NH}_{4}^{+}\right)$tanah pada 100 HST sebesar 4,7 kali lipat pada kedalaman 0-20 cm dan 3 kali lipat pada kedalaman $20-40 \mathrm{~cm}$ dari analisis awal. Nitrat $\left(\mathrm{NO}_{3}{ }^{-}\right)$ mengalami peningkatan sebesar 12 kali lipat pada kedalaman $0-20$ $\mathrm{cm}$ dan 9 kali lipat pada kedalaman 20-40 cm.

2. Penerapan sistem SRI yang dikombinasikan dengan pupuk hayati mampu mengurangi penggunaan pupuk Urea sebesar $131 \mathrm{~kg}$.

3. Populasi bakteri mengalami peningkatan 24,5 kali lipat pada kedalaman $0-20 \mathrm{~cm}$ dan 38 kali lipat pada kedalaman $20-40 \mathrm{~cm}$.

4. Hasil produksi yang paling baik berada pada perlakuan kombinasi pupuk hayati dengan NPK (1515-15) yaitu sebesar 8,42 $\mathrm{t} \mathrm{ha}^{-1}$.

\section{Daftar Pustaka}

Ayaga G, Todd A, Brookes P C. 2006. Enhanced biological cycling of phosphorus increases 
N.Istiqomah, T. N. Indarto, V. A. Nugroho dan C. Prayogo/ Buana Sains Vol 18 No 1:35-46

its availability to crops in lowinput sub-Saharan farming systems. Soil Biology and Biochemistry 38:81-90.

Badan Pusat Statistik. 2008. Berita Resmi Statistik.. http://www.bps.go.id. Diakses pada 8 Januari 2016

Balai Penelitian Tanah. 2007. Petunjuk Teknis: Metode Analisis Biologi Tanah. Bogor

Berkelaar, D. 2001. SRI, the system of rice intensification: less can be more. ECHO, Inc. 17391 Durrance Rd. North Ft. Myers FL. 33917 USA.

Chang, Yu-Chuan, Norman T. Uphoff, and Eiji Yamaji. 2015. A conceptual framework for ecofriendly paddy farming in Taiwan, based on experimentation with System of Rice Intensification (SRI) methodology. Paddy and Water Environment (Springer Link March 2015): 1-15. doi:10.1007/s10333-015-0488s-9

Damiri, A dan A. Ishak. 2011. Perbandingan Produktivitas Padi Sawah dengan Beberapa Model Plot Ubinan pada Sistem Tanaman Legowo 4:1. Balai Pengkajian Teknologi Pertanian Bengkulu

Dobermann, A. 2004. A critical assessment of the system of rice intensification (SRI). Agricultur System 79: 261-281.

Fageria, N. K. 2007. Agronomy and Physiology of Tropical Cover Crops. J. Plant Nutr., 30 (8) : 1287-1339

FAOSTAT. 2013. Food and Agriculture Organization of the United Nations. www.faostat3.fao.org. Diakses pada 2 Februari 2016
Gayathry G. 2002. Studies on dynamics of soil microbes in rice rhizosphere with water saving irrigation and in-situ weed incorporation. Ph.D. Thesis submitted to Tamil Nadu Agricultural University, Coimbatore, India.

Khidhir A. H., Flayeh A. J., Aqel Y. H. , Jassab A. H. E. , Norman U. 2011. Application of System of Rice Intensification (SRI) Methods on Productivity of Jasmine Rice Variety in Southern Iraq. Jordan Journal of Agricultural Sciences, 7(3).

Krupnik, T.J., Rodenburg, Shennan, C., dan Rodenburg, J. 2012. Yield, water productifity and nutrient balances under the System of Rice Intensification and Recommended Management Practices in the Sahel. Field Crops Research 130, 155-167.

Kyuma, K. 1995. Ecological Sustainability of the Paddy SoilRice System in Asia.

Latif, M.A., Ali, M.Y., Islam, M.R., Badshah, M.A., Hasan, M.S. 2009. Evaluation of management principles and performance of the System of Rice Intensification (SRI) in Bangladesh. Field Crops Research 114: 225-262.

Puspitawati, M D. 2013. Studi Mikroba Pelarut Fosfat Untuk Mengurangi Dosis Pupuk P Anorganik Pada Sistem Budidaya Padi Pengelolaan Tanaman Terpadu (PTT) dan System of Rice Intensification (SRI). Skripsi. Institut Pertanian Bogor 
N.Istiqomah, T. N. Indarto, V. A. Nugroho dan C. Prayogo/ Buana Sains Vol 18 No 1 : 35-46

Rajendran, K. dan V. Ganesa Raja. 2015.

Effect of system rice

intensification on microbial population, nutrient status, growth and yield of rice. International Journal of Agricultural Sciences 11(1): 24-29.

Ranjitha, 2014. Effect of Different Nutrient Management Options on Rice Under SRI Method of Cultivation- A Review.

Sinha, .K., Talati, J. 2007. Productivity impacts of the system of rice intensification (SRI): A case study in West Bengal, India. Agricultural Water Management 87: 55-60.

Tsujimoto, Y., T. Horie., H. Randriamihary., T. Shiraiwa., K. Homma. 2009. Soil management: The key factors for higher productivity in the fields utilizing the system of rice intensification (SRI) in the central highland of Madagascar. Agricultural Systems 100: 61-71

Uphoff, N., I. Anas, O. P. Rupela, A. K. Thakur, and T. M. Thiyagarajan. 2009. Learning about positive plant-microbial interactions from the System of Rice Intensification (SRI). Aspects of Applied Biology 98: $1-27$

Uphoff, N. 2003. Higher Yields with Fewer External Inputs? The System of Rice Intensification and Potential Contributions to Agricultural Sustainability. International Journal of Agricultural Sustainability 1 (1): 1 14 